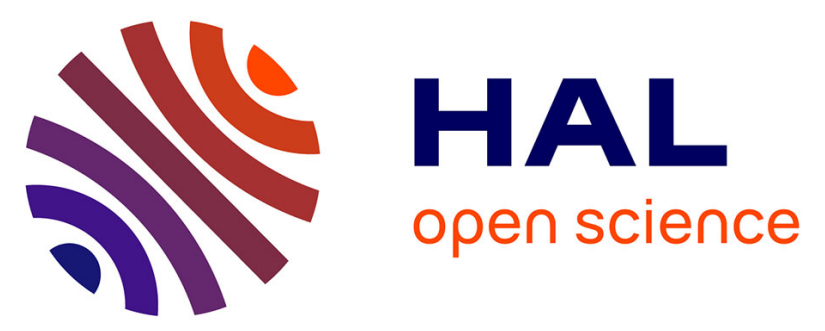

\title{
Patient-centered management of actinic keratosis. Results of a multi-center clinical consensus analyzing non-melanoma skin cancer patient profiles and field-treatment strategies
}

Wolfgang G. Philipp-Dormston, Maxime Battistella, Lise Boussemart, Alessandro Di Stefani, Paolo Broganelli, Kai-Martin Thoms

\section{To cite this version:}

Wolfgang G. Philipp-Dormston, Maxime Battistella, Lise Boussemart, Alessandro Di Stefani, Paolo Broganelli, et al.. Patient-centered management of actinic keratosis. Results of a multi-center clinical consensus analyzing non-melanoma skin cancer patient profiles and field-treatment strategies. Journal of Dermatological Treatment, 2020, 31 (6), pp.576-582. 10.1080/09546634.2019.1679335 . hal-02355726

HAL Id: hal-02355726

https://hal-univ-rennes1.archives-ouvertes.fr/hal-02355726

Submitted on 3 Feb 2020

HAL is a multi-disciplinary open access archive for the deposit and dissemination of scientific research documents, whether they are published or not. The documents may come from teaching and research institutions in France or abroad, or from public or private research centers.
L'archive ouverte pluridisciplinaire HAL, est destinée au dépôt et à la diffusion de documents scientifiques de niveau recherche, publiés ou non, émanant des établissements d'enseignement et de recherche français ou étrangers, des laboratoires publics ou privés. 


\section{Patient-centered management of actinic keratosis. Results of a multi-center} clinical consensus analyzing non-melanoma skin cancer patient profiles and

\section{field-treatment strategies}

Short title: Patient-centered management of actinic keratosis

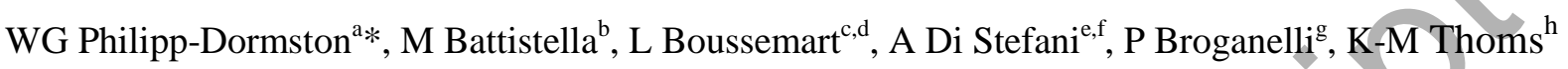

${ }^{a}$ Hautzentrum Köln (Cologne Dermatology), Klinik Links vom Rhein, Köln, Germany, Faculty of Health, University Witten-Herdecke, Witten, Germany, ${ }^{b}$ Anatomie et cytologie pathologiques, Hôpital Saint-Louis, AP-HP, Université Paris 7, Paris, France; ${ }^{c}$ Department of Dermatology, Pontchaillou Hospital, CHU de Rennes, F-35000 Rennes, France; ${ }^{d}$ Universite Rennes, CNRS, IGDR, UMR 6290, F-35000 Rennes, France; ${ }^{e}$ Institute of Dermatology, Catholic University of the Sacred Heart, Rome, Italy; ${ }^{f}$ Fondazione Policlinico Universitario A. Gemelli IRCCS, Rome, Italy; ${ }^{g} S C$ Dermatology U, City of Health and Science of Turin, Italy; ${ }^{h}$ Department of Dermatology, Venereology and Allergology, University Medical Center Göttingen, Göttingen, Germany

*Corresponding author: WG Philipp-Dormston; Hautzentrum Köln (Cologne Dermatology), Klinik Links vom Rhein, Köln, Germany; Tel: +49 22139800 200/-201; E-mail: mail@ hautzentrum.com 


\section{Patient-centered management of actinic keratosis. Results of a multi-center clinical consensus analyzing non-melanoma skin cancer patient profiles and}

\section{field-treatment strategies}

Abstract

Introduction: Actinic keratosis (AK) is a chronic skin condition that can be a precursor to cutaneous squamous cell carcinoma. AK can recur and patients are likely to undergo multiple treatments. It is important that AK lesions are managed appropriately, and that patients are involved in treatment decisions.

Materials and methods: The Supporting Professional Expertise in AK (SPEAK) program aims to facilitate this patient-centered care by identifying patient needs and aiding healthcare practitioners (HCPs) in selecting optimal treatment and communication strategies for different types of patients. Twenty-two dermatooncologists with established expertise in the treatment of AK collaborated to describe commonly encountered psychosocial patient profiles, and to develop respective communication and treatment strategies.

Results and conclusion: Six patient profiles were defined based on different psychosocial characteristics and were used to develop appropriate management approaches. We provide a systematic way of identifying these patient profiles in clinical practice and we outline communication strategies tailored to the primary needs of each type of patient. In addition, we provide recommendations for potential fieldtreatments that may be best suited for each profile. The recommendations provided here may help improve the communication and relationship between patients and HCPs, resulting in higher treatment adherence and improved patient outcomes.

Keywords: actinic keratosis, cutaneous squamous cell carcinoma, management 


\section{Introduction}

Actinic keratosis (AK), a chronic skin condition caused predominately by prolonged exposure to ultraviolet (UV) radiation, is a precursor to cutaneous squamous cell carcinoma (SCC). Estimates range from $0.1-10 \%$ of $\mathrm{AK}$ progressing to $\mathrm{SCC}_{[1,2]}$; in addition, approximately $97 \%$ of cutaneous SCCs are contiguous to an $\mathrm{AK}_{[3]}$, which may represent carcinoma in situ [4].

Whilst many AK lesions resolve spontaneously, some can be potentially inyasive, regardless of their intra-epidermal thickness ${ }_{[2,5]}$, and it is not possible to draw conclusions about the histology of AK lesions from their clinical appearance ${ }_{[6]}$. For this reason, coupled with a lack of supporting long-term prognostic studies, it is important that AK lesions are managed appropriately ${ }_{[2]}$. Appropriate management of AK can be in the form of lesionspecific or field-directed therapy. Visible AK lesions can arise from subclinical changes that affect a wider area of skin, a process known as cancerization, ${ }_{[3,7]}$ in these instances a fielddirected therapy may be advantageous allowing effective treatment of sub-clinical AK lesions that may be missed with lesion-specific therapy. Moreover, current studies have highlighted, that the potential to develop squamous cell carcinomas is associated with subclinical basal proliferating AKs as well as clinical hyperkeratotic AKs, indicating a need for standardized, and approved field therapy $y_{[8,9]}$ When deciding on a management strategy it is important to consider a multitude of factors, including treatment duration, compliance, cost and risk factors for recurrence and the age of the patient.[2]

In addition, patients increasingly expect to be involved in decision-making about treatments, especially as AK can recur and people with AK are likely to need multiple treatment courses throughout their lifetime. [10] Therefore, a practical tool that takes into 
account patient-related factors may be particularly useful for assisting doctors in optimizing the efficiency of their consultations.

Indeed, patient-centric care is now a widely accepted part of high-quality healthcare in general, and seems to improve outcomes, quality of life, satisfaction and treatment adherence. Patient-centric care may also aid the adoption of patient-defined treatment goals and outcomes, [11] and in turn, help manage expectations.

Based on this, the Supporting Professional Expertise in AK (SPEAK) program aims to facilitate patient-centric care in $\mathrm{AK}$ management, focusing on ways to appropriately identify the needs of different patients, and aid the physicians in selecting the best field-directed therapy for each patient in an effective and efficient way. The patient profiles and communication strategies developed in the program are outlined in this article and treatment recommendations for different patient profiles are discussed.

\section{Materials and methods}

In total, 22 dermatologists with expertise in the management of AK participated in a twostage process, across four meetings, to develop these clinical profiles and recommendations.

Prerequisite conditions for expert involvement in the multi-center consensus analysis were specialization in dermato-oncology; consistent, long-term clinical treatment experience with non-melanoma skin cancer (NMSC) patients; and sole therapeutic responsibly within a certified skin cancer center. All participating experts met the conditions for inclusion.

In the first stage, consensus meetings were held in Frankfurt, Germany; Paris, France; and Rome, Italy. Discussions were facilitated in the local language, and patient profiles were 
developed based on typical patient types commonly encountered by the participating experts in their clinical practice.

During the second stage, six practicing experts represented the national consensus meetings by attending a final meeting in London, United Kingdom, to consolidate the patient profiles developed at a national level. Based on these profiles, the experts developed recommendations for the clinical management and optimal communication approach for each patient type in two smaller groups. Recommendations were discussed within the six-member group and agreed by consensus, after which the experts discussed each of the patient profiles individually and adjusted the recommendations until a unanimous agreement was met.

Therefore, the recommendations in this document represent the expert consensus opinion regarding strategies and techniques that can guide the individualization of AK management. Nevertheless, the experts recognize that each healthcare practitioner (HCP) needs to precisely tailor treatment and communication to each individual patient.

\section{Results}

\section{Recommendations}

This section includes the characteristics of each patient profile (as defined by clinical experts); questions that can be used to identify each patient profile in clinical practice; and management priorities as well as treatment recommendations for each patient profile.

We summarized the main attributes of six patient profiles (Table 1). An individual patient may not fit exactly into any one particular profile and some people with AK may have characteristics custom of more than one profile: e.g. an academic biologist, geologist or archaeologist working in the field may develop occupational AK. Nevertheless, the profiles 
offer a heuristic method to identify an appropriate management approach and consultation style that can guide discussions about $\mathrm{AK}$ and facilitate the optimal approach to treatment. For instance, a patient who is anxious about the diagnosis or treatment may benefit from reassurance about the likelihood of malignant transformation, or the systemic effects and safety of treatment, respectively.

AK is typically diagnosed on clinical grounds, ${ }_{[10]}$ so taking a detailed patient history is mandatory prior to identifying the profile category a patient best identifies with; determined using answers to a questionnaire (Table 2). For instance, the concerns and needs of the patients identified can be linked to the appropriate anxious or concerned profile groups, whereas their knowledge and level of engagement can also provide useful insight to categorizing them into the right profile.

It should be noted that immunocompromised patients, who may be at risk of diffuse $\mathrm{AK}$ and may be receiving immunosuppressive therapies, can display any of the proposed profiles. When evaluating the communication and treatment strategy for these patients, it is important to consider both the type of profile describing each patient and also the fact that they present with immunosuppression. Therefore, these patients may also need to be treated at multiple areas simultaneously and may require additional therapies for the management of severe local skin reactions.

[INSERT TABLE 1 HERE]

[INSERT TABLE 2 HERE] 
This section details how the identified patient profiles can be used to deliver patient-centric management of AK, where the relationship between patient and HCP is built on effective communication, empathy and a feeling of partnership. [12]

Against this background, we outline recommended management priorities and potential treatments to consider for each of the patient profiles (Table 3). For example, in the panel's experience, people who developed AK following occupational exposure need a fast, effective regimen with a short duration of treatment, especially as their potentially low engagement with the disease could translate into poor adherence.

The panel recommends adapting HCP communication style to meet the primary needs of each patient profile (Table 4). For example, HCPs may need to reassure people who are concerned about the cosmetic outcomes that short-term skin reactions, which are common with topical treatments, do not influence long-term aesthetic outcomes and are a result of the treatment being effective, rather than simply being a side effect accompanying the treatment.

\section{Using appropriate terminology when speaking to patients}

To deliver education within a patient-centric framework, we recommend HCPs ensure that discussions about AK build on each patient's existing knowledge and reflect their expectations and concerns. This means using appropriate terminology and establishing the introductory terminology, such as explaining the chronic nature of AK. Moreover, the terminology used during a discussion of the same topic could differ markedly for people who develop AK following occupational exposure, and for those patients who are more knowledgeable, reflecting their different levels of health literacy.

An important communication goal is to ensure patients understand the normal role of local skin reactions in $\mathrm{AK}$ treatment, and that they appreciate them as a positive indication of 
the treatment's function. We advise that HCPs aim to help patients become familiar with any management approaches that might reduce the severity of local reactions and educate patients on when to seek further assistance. Prescribing treatments such as photodynamic therapy (PDT) or ingenol mebutate that have well-characterized and predictable reactions may simplify these discussions.

\section{[INSERT TABLE 3 HERE]}

[INSERT TABLE 4 HERE]

[INSERT TABLE 5 HERE]

\section{General treatment recommendations}

The panel identified which treatments may be recommended for different patients based on their individual profile and characteristics (Table 5). For instance, these recommendations take into account which therapies may be associated with unpredictable local skin reactions or variable outcomes compared with good aesthetic long-term outcomes, and how aspects of each therapy might be perceived by patients of different profiles.

\section{Practical recommendations for application of topical treatments}

HCPs should communicate clearly to patients the exact area over which they, or a carer (e.g. for inaccessible parts of the body), should apply a topical treatment.

Alternatively, HCPs could provide patients who have smartphones with digital cameras, a photographic reference for the area being treated. A photographic reference can be particularly helpful for formulations with long treatment durations or if the HCP and patient agree to postpone the start of treatment. 
Educational brochures that provide skin maps; illustrations of the appearance of skin and lesions before, during and after treatment; as well as those showing local skin reactions, are available. Experts stress the importance of such detailed, up-to-date leaflets to provide patients with information about treatment options and facilitate their discussions with HCPs.

\section{Discussion}

The panel intends to raise awareness of the optimal management of AK, providing it as an educational resource, as well as helping HCPs implement local and national treatment guidelines in their daily clinical practice. The patient profiles and related recommendations in this document are intended as a pragmatic and heuristic guide to support patient management based on their main characteristics.

In order to support the individualization of treatment for patients with $\mathrm{AK}$, the present recommendations go beyond the treatment-focused, disease-driven framework typically used, [4,13] and take into account patient-related factors that are often neglected by guidelines and recommendations. [14] In particular, the educational messages about AK can be tailored according to each patient's profile by using appropriate terminology that is adjusted to each patient's educational background. This 'consumerist' model of interaction between patient and HCP is generally increasingly common in medicine. ${ }_{[15]}$ Similarly, the suggested guide provides a patient-centric framework with recommendations to support optimal management and physician-patient communication in order to cultivate empathy and a feeling of partnership. $[12,16]$

For many cases of AK, several treatment approaches are potentially suitable based on existing guidelines. This document therefore further complements existing guidelines and previous consensus papers by providing recommendations about selecting the appropriate 
treatment based on the psychosocial needs of different patient profiles and counselling patients about appropriate use.

Ingenol mebutate was one of the treatment options proposed for many of the profiles and this was driven by its association with good cosmetic outcomes ${ }_{[17,18]}$; the predictable nature of the treatment and related short-term local skin reactions ${ }_{[19-22]}$; and the fact that the administration regimen of ingenol mebutate allows for flexible use, as patients are able to decide how and when it is used according to their needs and individual condition. In a randomized, evaluator-blinded trial of ingenol mebutate $0.015 \%$ gel and diclofenac sodium $3 \%$ gel, patients experienced a shorter duration of skin reactions, with a peak after one week, with ingenol mebutate compared with diclofenac sodium, who experienced reactions throughout the 90-day treatment. [3] These attributes support ingenol mebutate, in the panel's opinion, as a viable option for many of the patient profiles; assuming its use is complemented by treatment-focused education delivered at treatment initiation. [23] Despite the presence of local skin reactions, a study of 274 patients using ingenol mebutate reported that $98.2 \%$ of patients were adherent to the 3-day administration regimen. ${ }_{\text {[24] }}$ Collectively, this evidence supports the panel's recommendation that ingenol mebutate therapy in patients that are welleducated by their dermatologist can lead to consistent, standardized and effective outcomes, with predictable, short-term local skin reactions.

In addition to ingenol mebutate, conventional photodynamic therapy (PDT) was also identified as a viable option for a number of patient profiles, particularly for patients that may be concerned with cosmetic outcomes during or after treatment. The quality of the cosmetic outcomes associated with PDT ${ }_{[24-26]}$ were identified as key drivers for choosing this therapy, as they might reassure and better satisfy patients who are particularly concerned about this. Indeed, PDT was also associated with the highest quality of life ratings, alongside ingenol 
mebutate, ${ }_{[14]}$ Similarly, daylight PDT was also recommended, as it has comparable efficacy to conventional PDT for the resolution of AK in the face or scalp, and has been shown to effectively treat AK lesions in a home-based setting. [27] Patients have also reported reduced pain and higher satisfaction with its convenience and outcomes compared with conventional PDT, [28-30] as well as compared with imiquimod. [31] Finally, although imiquimod may not be the treatment of choice for everyone due to the unpredictable onset of local skin reactions and the potential of systemic adverse events, it should be highlighted that imiquimod has high efficacy in reducing AK lesions [32-34] regardless of disease severity, [35] and has been associated with good long-term, post-treatment cosmetic outcomes. [31] Therefore, it could also be considered as a viable option for appropriate patients.

Although commonly used, the panel does not recommend cryotherapy, as a lesion-directed treatment for the patient profiles discussed (Table 5), due to the potential for missing subclinical lesions, scarring, highly variable short and long term outcomes based on experience, and the requirement for multiple rounds of treatment.

In conclusion, there is a need for further research and comparative studies to facilitate the development of evidence-based guidelines that use objective criteria to stratify AK patients.

In the meantime, the authors hope that a mutualistic, patient-centric relationship, ${ }_{[15]}$ aided by the guide developed here will improve patient and HCP satisfaction with diagnosis and treatment outcomes. Such a relationship could potentially improve adherence and persistence with topical therapy for AK; avoid patients misinterpreting an unpleasant skin reaction during treatment; optimize the use of time during consultations and follow-up; and ultimately result in improved outcomes, safety and satisfaction. 


\section{Acknowledgements}

The authors thank Real Science for writing and editorial support, which was funded by LEO Pharma A/S.

\section{Declaration of interest}

MB has received honoraria from Leo Pharma A/S, Bristol-Myers-Squibb, Innate Pharma and Takeda. WPD has received honoraria from Allergan, Almirall, Biofrontera, Galderma and Leo Pharma A/S. PB has received honoraria from LEO Pharma A/S, Almirall and Galderma. LB has received research funding from Leo Pharma A/S. LB is a consultant for Pierre Fabre and Novartis. KMT has received honoraria from Leo Pharma A/S, Galderma, Bristol-Myers Squibb, MSD, Roche, Novartis Oncology and Pierre Fabre Oncology. ADS has received honoraria from Almirall, Leo Pharma A/S and Pierre Fabre Oncology.

\section{Author contributions}

All authors made contributions to the development and consolidation of the patient profiles detailed in this paper. Based on these profiles, each of the experts developed recommendations for the clinical management and optimal communication approach for each patient type, which were then adjusted until there was unanimous agreement. All authors have contributed equally to the paper and have given it their final approval. 


\section{References}

1. Salasche SJ. Epidemiology of actinic keratoses and squamous cell carcinoma. J Am Acad Dermatol [Internet]. 2000;42(1):S4-7. Available from:

http://linkinghub.elsevier.com/retrieve/pii/S0190962200492285

2. Feldman SR, Jr ABF. Progression of Actinic Keratosis to Squamous Cell Carcinoma Revisited. 2011;87(April):201-7.

3. Stockfleth E. The importance of treating the field in actinic keratosis. J Eur Acad Dermatology Venereol. 2017;31:8-11.

4. Dréno B, Amici JM, Basset-Seguin N, Cribier B, Claudel JP, Richard MA. Management of actinic keratosis: A practical report and treatment algorithm from AKTeam $^{\text {TM }}$ expert clinicians. J Eur Acad Dermatology Venereol. 2014;28(9):1141-9.

5. Fernández-Figueras MT, Carrato C, Sáenz X, Puig L, Musulen E, Ferrándiz C, et al. Actinic keratosis with atypical basal cells (AK I) is the most common lesion associated with invasive squamous cell carcinoma of the skin. J Eur Acad Dermatology Venereol [Internet]. 2014 Nov 26;29(5):991-7. Available from: https://doi.org/10.1111/jdv. 12848

6. Schmitz L, Kahl P, Majores M, Bierhoff E, Stockfleth E, Dirschka T. Actinic keratosis: correlation between clinical and histological classification systems. J Eur Acad Dermatology Venereol [Internet]. 2016 Mar 8;30(8):1303-7. Available from: https://doi.org/10.1111/jdv.13626

7. Philipp-Dormston WG. Field Cancerization: From Molecular Basis to Selective FieldDirected Management of Actinic Keratosis. In: Current Problems in Dermatology [Internet]. 2015. p. 115-21. Available from: https://www.karger.com/DOI/10.1159/000366547

8. Schmitz L, Gambichler T, Kost C, Gupta G, Stücker M, Stockfleth E, et al. Cutaneous 
squamous cell carcinomas are associated with basal proliferating actinic keratoses. Br J Dermatol [Internet]. 2019;180(4):916-21. Available from:

https://doi.org/10.1111/bjd.16536

9. Schmitz L, Grinblat B, Novak B, Hoeh A-K, Händschke K, von Dobbeler C, et al. Somatic mutations in kinetochore gene KNSTRN are associated with basal proliferating actinic keratoses and cutaneous squamous cell carcinoma. J Eur Acad Dermatology Venereol [Internet]. 0(0). Available from: https://doi.org/10.1111/jdv.15615

10. de Berker D, McGregor JM, Mohd Mustapa MF, Exton LS, Hughes BR. British Association of Dermatologists' guidelines for the care of patients with actinic keratosis 2017. Br J Dermatol. 2017;176(1):20-43.

11. Corriere MA, Avise JA, Peterson LA, Stafford JM, Easterling D, Boone DS, et al. Exploring patient involvement in decision making for vascular procedures Presented at the Thirty-ninth Annual Meeting of the Southern Association for Vascular Surgery, Scottsdale, Ariz, January 14-17, 2015. J Vasc Surg [Internet]. 2015;62(4):10321039e2. Available from: http://dx.doi.org/10.1016/j.jvs.2015.04.443

12. Cerio R. The importance of patient-centred care to overcome barriers in the management of actinic keratosis. J Eur Acad Dermatology Venereol. 2017;31:17-20.

13. Peris K, Calzavara-Pinton PG, Neri L, Girolomoni G, Malara G, Parodi A, et al. Italian expert consensus for the management of actinic keratosis in immunocompetent patients. J Eur Acad Dermatology Venereol. 2016;30(7):1077-84.

14. Khanna R, Bakshi A, Amir Y, Goldenberg G. Patient satisfaction and reported outcomes on the management of actinic keratosis. Clin Cosmet Investig Dermatol. 2017;10:179-84.

15. Russell. Summary of the consultation. In p. 82. 
16. Boussemart L, Bouzillé G, Boyer A, Arnheiter H, Dupuy A. Do personality profiles among physicians correlate with their career choices? MedEdPublish [Internet]. 2016;5(2):1-22. Available from: http://www.mededpublish.org/manuscripts/461/v1

17. Handler MZ, Bloom BS, Goldberg DJ. Clinical and Histologic Evaluation of Ingenol Mebutate $0.015 \%$ Gel for the Cosmetic Improvement of Photoaged Skin. 2017;1-7.

18. Wu DC, Guiha I, Goldman MP. A prospective clinical trial to evaluate the efficacy and safety of topical therapy with ingenol mebutate gel $0.015 \%$ for actinic keratosis on an expanded area of the chest. J Clin Aesthetic Dermatology. 2017;10:31-6.

19. Stockfleth E, Bastian M. Pharmacokinetic and pharmacodynamic evaluation of ingenol mebutate for the treatment of actinic keratosis. Expert Opin Drug Metab Toxicol [Internet]. 2018 Sep 2;14(9):911-8. Available from: https://doi.org/10.1080/17425255.2018.1508449

20. Neri L, Peris K, Longo K, Calvieri S, Franscione P, Parodi A, et al. Physician-Patient Communication and Patient-Reported Outcomes in the Actinic Keratosis TReatmentAdherence INitiative (AK-TRAIN): A Multicenter, Prospective, Real- Life study of Treatment Satisfaction, Quality of Life and Adherence to topical field-direct. J Eur Acad Dermatology Venereol [Internet]. 2018; Available from: https://doi.org/10.1111/jdv.15142

21. Carbotti M, Coppola R, Zanframundo S, Devirgiliis V, Panasiti V. Clinical Study Efficacy of Ingenol Mebutate in the Treatment of Actinic Keratoses: A Pre-and Posttreatment Dermoscopic Comparative Analysis. 2018;2018. Available from: https://doi.org/10.1155/2018/4381019

22. Longo C, Neri L, Argenziano G, Calvieri S, Calzavara-Pinton PG, Cantisani C, et al. Management of local skin reactions after the application of ingenol mebutate gel for the treatment of actinic keratosis: four illustrative cases. J Eur Acad Dermatology 
Venereol [Internet]. 2014 Sep 3;30(2):320-1. Available from: https://doi.org/10.1111/jdv.12714

23. Braun S, Gerber P. Cosmetic effects of ingenol mebutate gel in the treatment of fieldcancerized photodamaged skin. Dermatology Surg. 2015;1-2.

24. Lebwohl M, Swanson N, Anderson LL, Melgaard A, Xu Z, Berman B. Ingenol Mebutate Gel for Actinic Keratosis. N Engl J Med [Internet]. 2012;366(11):1010-9. Available from: http://www.nejm.org/doi/abs/10.1056/NEJMoa1111170

25. Augustin M, Tu JH, Knudsen KM, Erntoft S, Larsson T, Hanke CW. Ingenol mebutate gel for actinic keratosis: The link between quality of life, treatment satisfaction, and clinical outcomes. J Am Acad Dermatol [Internet]. 2015 May 1;72(5):816-21. Available from: https://doi.org/10.1016/j.jaad.2015.01.036

26. Lebwohl M, Shumack S, Gold L, Melgaard A, Larsson T, SK T. Long-term follow-up study of ingenol mebutate gel for the treatment of actinic keratoses. JAMA Dermatology [Internet]. 2013 Jun 1;149(6):666-70. Available from: http://dx.doi.org/10.1001/jamadermatol.2013.2766

27. Wiegell SR, Wulf HC, Szeimies RM, Basset-Seguin N, Bissonnette R, Gerritsen MJP, et al. Daylight photodynamic therapy for actinic keratosis: An international consensus: International Society for Photodynamic Therapy in Dermatology. J Eur Acad Dermatology Venereol. 2012;26(6):673-9.

28. Sotiriou E, Evangelou G, Papadavid E, Apalla Z, Vrani F, Vakirlis E, et al. Conventional vs. daylight photodynamic therapy for patients with actinic keratosis on face and scalp: 12-month follow-up results of a randomized, intra-individual comparative analysis. J Eur Acad Dermatology Venereol. 2018;32(4):595-600.

29. Rubel DM, Spelman L, Murrell DF, See JA, Hewitt D, Foley P, et al. Daylight photodynamic therapy with methyl aminolevulinate cream as a convenient, similarly 
effective, nearly painless alternative to conventional photodynamic therapy in actinic keratosis treatment: A randomized controlled trial. Br J Dermatol. 2014;171(5):116471.

30. Morton CA, Wulf HC, Szeimies RM, Gilaberte Y, Basset-Seguin N, Sotiriou E, et al. Practical approach to the use of daylight photodynamic therapy with topical methyl aminolevulinate for actinic keratosis: A European consensus. J Eur Acad Dermatology Venereol. 2015;29(9):1718-23.

31. Sotiriou E, Apalla Z, Maliamani F, Zaparas N, Panagiotidou D, Ioannides D. Intraindividual, right-left comparison of topical 5-aminolevulinic acid photodynamic therapy vs. 5\% imiquimod cream for actinic keratoses on the upper extremities. J Eur Acad Dermatology Venereol [Internet]. 2009 Jul 29;23(9):1061-5. Available from: https://doi.org/10.1111/j.1468-3083.2009.03259.x

32. Swanson N, Abramovits W, Berman B, Kulp J, Rigel DS, Levy S. Imiquimod $2.5 \%$ and $3.75 \%$ for the treatment of actinic keratoses; Results of two placebo-controlled studies of daily application to the face and balding scalp for two 2-week cycles. J Am Acad Dermatol [Internet].2010;62(4):582-90. Available from: http://dx.doi.org/10.1016/j.jaad.2009.07.004

33. Serra-Guillén C, Nagore E, Hueso L, Traves V, Messeguer F, Sanmartín O, et al. A randomized pilot comparative study of topical methyl aminolevulinate photodynamic therapy versus imiquimod 5\% versus sequential application of both therapies in immunocompetent patients with actinic keratosis: Clinical and histologic outcomes. J Am Acad Dermatol. 2012;66(4):131-7.

34. Hanke CW, Beer KR, Stockfleth E, Wu J, Rosen T, Levy S. Imiquimod 2.5\% and $3.75 \%$ for the treatment of actinic keratoses: Results of two placebo-controlled studies of daily application to the face and balding scalp for two 3-week cycles. J Am Acad 
Dermatol [Internet]. 2010 Apr 1;62(4):573-81. Available from:

https://doi.org/10.1016/j.jaad.2009.06.020

35. Peris K, Stockfleth E, Gupta G, Aractingi S, Dakovic R, Dirschka T, et al. Efficacy of imiquimod 3.75\% from Lmax according to the number of actinic keratosis lesions. J Eur Acad Dermatology Venereol. 2015;29(12):2470-3. 
Table 1: Common AK patient profiles encountered in clinical practice

\begin{tabular}{|c|c|c|c|c|c|c|}
\hline Profile & $\begin{array}{l}\text { 1. Unengaged (low } \\
\text { medical engagement) }\end{array}$ & $\begin{array}{l}\text { 2. Cosmetic } \\
\text { concerned } \\
\text { during treatment }\end{array}$ & $\begin{array}{l}\text { 3. Cosmetic } \\
\text { concerned post- } \\
\text { treatment }\end{array}$ & $\begin{array}{l}\text { 4. Knowledgeable } \\
\text { (high medical } \\
\text { engagement) }\end{array}$ & $\begin{array}{l}5 . \\
\text { Diagnosis- } \\
\text { anxious }\end{array}$ & 6. Safety-anxious \\
\hline Description & $\begin{array}{l}\text { Often occupational } \\
\text { UV exposure }\end{array}$ & $\begin{array}{l}\text { Concerned with } \\
\text { local skin } \\
\text { reactions during } \\
\text { treatment }\end{array}$ & $\begin{array}{l}\text { Concerned with } \\
\text { permanent cosmetic } \\
\text { outcomes post- } \\
\text { treatment }\end{array}$ & $\begin{array}{l}\text { Well-informed } \\
\text { patient }\end{array}$ & $\begin{array}{l}\text { Anxious } \\
\text { about } \\
\text { malignant } \\
\text { diagnosis }\end{array}$ & $\begin{array}{l}\text { Anxious about } \\
\text { general and long- } \\
\text { term adverse } \\
\text { effects of }\end{array}$ \\
\hline $\begin{array}{l}\text { Clinical } \\
\text { characteristic }\end{array}$ & $\begin{array}{l}\text { Severe photodamage } \\
\text { Field cancerization } \\
\text { present } \\
\text { Scalp involvement } \\
\text { Trunk and dorsum of } \\
\text { the hands involvement } \\
\text { Male > female } \\
\text { Older age }\end{array}$ & $\begin{array}{l}\text { Moderate, } \\
\text { diffuse } \\
\text { photodamage } \\
\text { Facial } \\
\text { involvement } \\
\text { Female > male }\end{array}$ & $\begin{array}{l}\text { Mild to moderate, } \\
\text { diffuse } \\
\text { photodamage, } \\
\text { sun exposure } \\
\text { mainly in the past } \\
\text { Facial involvemen } \\
\text { Female > male } \\
\text { Younger }\end{array}$ & $\begin{array}{l}\text { Moderate } \\
\text { photodamage } \\
\text { Facial } \\
\text { involvement }\end{array}$ & $\begin{array}{l}\text { stage disease } \\
\text { Facial } \\
\text { involvement }\end{array}$ & $\begin{array}{l}\text { Moderate } \\
\text { photodamage } \\
\text { Facial } \\
\text { involvement }\end{array}$ \\
\hline $\begin{array}{l}\text { Psychosocial } \\
\text { characteristics }\end{array}$ & $\begin{array}{l}\text { Employment possibly } \\
\text { involves working } \\
\text { outdoors } \\
\text { Lower level of formal } \\
\text { education } \\
\text { Unconcerned about } \\
\text { disease }\end{array}$ & $\begin{array}{l}\text { Employment } \\
\text { involves } \\
\text { interaction with } \\
\text { others } \\
\text { High } \\
\text { occupational } \\
\text { status and } \\
\text { responsibility } \\
\text { without } \\
\text { allowance for } \\
\text { work } \\
\text { interruption due }\end{array}$ & $\begin{array}{l}\text { Employment } \\
\text { involves interaction } \\
\text { with others } \\
\text { Exposed } \\
\text { occupational } \\
\text { position in face-to- } \\
\text { face relationships } \\
\text { (particularly in the } \\
\text { field of customer } \\
\text { relationships) } \\
\text { Willingness for } \\
\text { downtime but not }\end{array}$ & $\begin{array}{l}\text { Highly educated } \\
\text { Internet and } \\
\text { research literate } \\
\text { Well-informed } \\
\text { about AK } \\
\text { treatments }\end{array}$ & $\begin{array}{l}\text { Worried/hyp } \\
\text { er-concerned } \\
\text { Tendency to } \\
\text { be cancer- } \\
\text { phobic } \\
\text { Regular } \\
\text { engagement } \\
\text { with } \\
\text { healthcare } \\
\text { High } \\
\text { treatment } \\
\text { motivation }\end{array}$ & $\begin{array}{l}\text { High level of } \\
\text { social interaction } \\
\text { Well-informed - } \\
\text { able to use the } \\
\text { internet }\end{array}$ \\
\hline
\end{tabular}




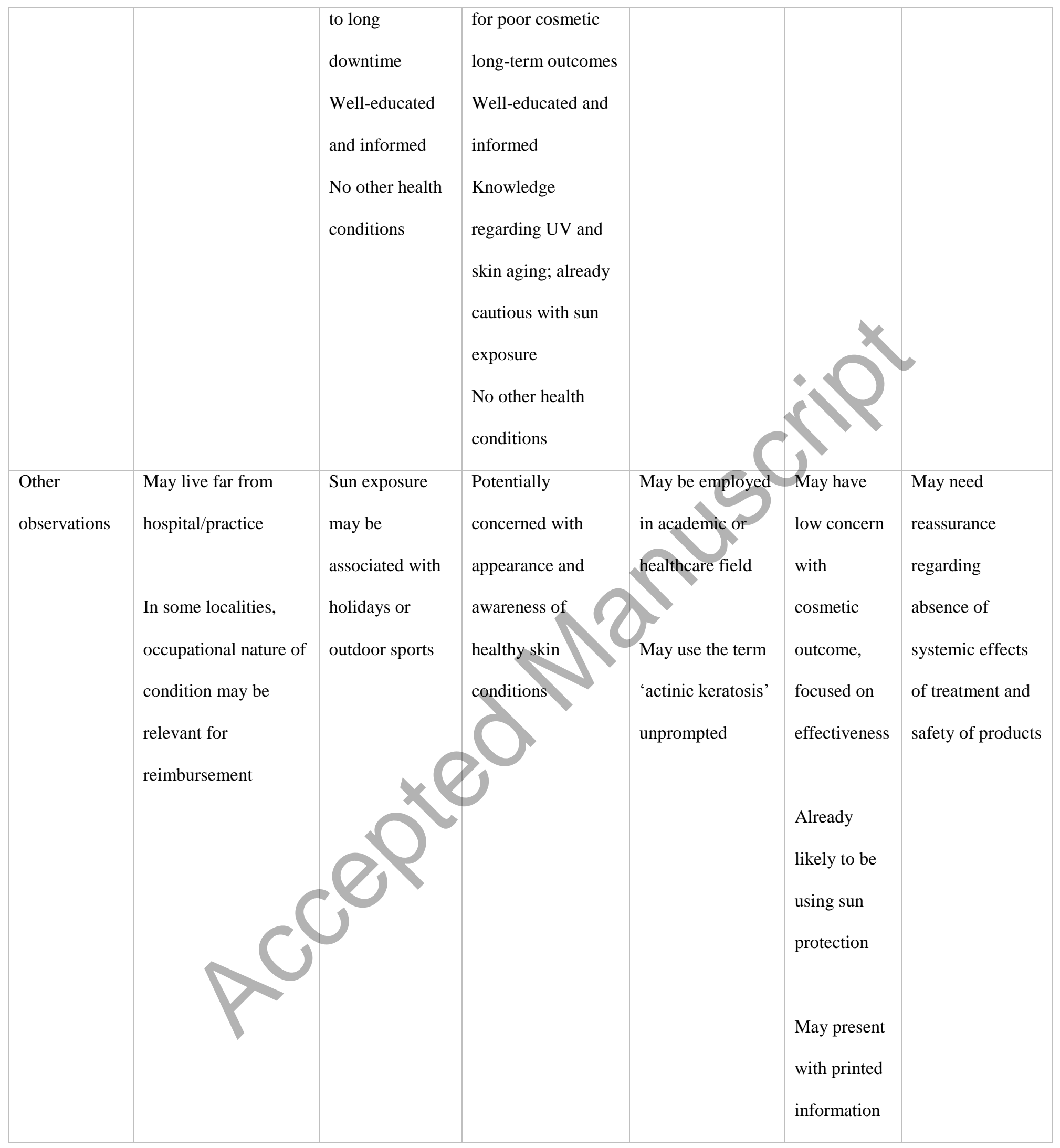


Table 2: Questions to support identification of patient profile

\begin{tabular}{|c|c|}
\hline Question & Potential profile identification \\
\hline $\begin{array}{l}\text { What is your main concern } \\
\text { about your skin? }\end{array}$ & $\begin{array}{l}\text { Focus in response on cosmetic appearance during or after treatment } \\
\text { may suggest cosmetic concerned profile } \\
\text { Focus in response on skin cancer may suggest safety-anxious profile }\end{array}$ \\
\hline $\begin{array}{l}\text { What's your occupation? } \\
\text { Do you/did you work } \\
\text { outdoors? }\end{array}$ & $\begin{array}{l}\text { Outdoor work may suggest profile with low medical engagement } \\
\text { Occupations involving high levels of personal interaction (service } \\
\text { industry, sales, etc.) may suggest cosmetic concern or safety-anxious } \\
\text { profiles }\end{array}$ \\
\hline $\begin{array}{l}\text { Does your appearance } \\
\text { matter in your job or daily } \\
\text { life? }\end{array}$ & $\begin{array}{l}\text { Positive response may suggest cosmetic concerned or safety-anxious } \\
\text { profile }\end{array}$ \\
\hline $\begin{array}{l}\text { What do you expect from } \\
\text { treatment? }\end{array}$ & $\begin{array}{l}\text { A focus on cosmetic outcomes may suggest cosmetic concerned } \\
\text { profile } \\
\text { A high level of detail in response may suggest knowledgeable or } \\
\text { safety-anxious profile } \\
\text { A focus on the potential for pain or discomfort may suggest a safety- }\end{array}$ \\
\hline $\begin{array}{l}\text { Would you accept } \\
\text { downtime during treatment? }\end{array}$ & $\begin{array}{l}\text { Using a term common in cosmetic treatment may help identify patients } \\
\text { who match the cosmetic concerned profile }\end{array}$ \\
\hline $\begin{array}{l}\text { Would you be bothered by } \\
\text { short-term local skin } \\
\text { reactions? Do you care } \\
\text { about scarring or }\end{array}$ & $\begin{array}{l}\text { These questions may help distinguish between cosmetic concerned } \\
\text { during and post-treatment profiles }\end{array}$ \\
\hline
\end{tabular}




\begin{tabular}{|l|l|}
\hline $\begin{array}{l}\text { hyperpigmentation? } \\
\text { What do you already know }\end{array}$ & A focus in response on the visual appearance of local skin reactions \\
$\begin{array}{l}\text { about AK and the } \\
\text { treatments? }\end{array}$ & $\begin{array}{l}\text { A high level of knowledge may suggest knowledgeable or diagnosis- } \\
\text { anxious profile }\end{array}$ \\
\hline A focus in response on the transformation of AK into SCC may \\
\hline suggest diagnosis-anxious profile \\
\hline Do you have any & A positive response may indicate knowledgeable profile \\
\hline preferences for your & \\
\hline treatment? & \\
\hline
\end{tabular}


Table 3: Suggested management priorities for commonly encountered AK patient profiles

\begin{tabular}{|c|c|c|c|c|c|c|}
\hline Profile & $\begin{array}{l}\text { Unengaged } \\
\text { (low } \\
\text { medical } \\
\text { engagement) }\end{array}$ & $\begin{array}{l}\text { Cosmetic } \\
\text { concerned during } \\
\text { treatment }\end{array}$ & $\begin{array}{l}\text { Cosmetic concerned } \\
\text { post-treatment }\end{array}$ & $\begin{array}{l}\text { Knowledgeable } \\
\text { (high medical } \\
\text { engagement) }\end{array}$ & $\begin{array}{l}\text { Diagnosis- } \\
\text { anxious }\end{array}$ & $\begin{array}{l}\text { Safety- } \\
\text { anxious }\end{array}$ \\
\hline $\begin{array}{l}\text { Primary } \\
\text { need }\end{array}$ & $\begin{array}{l}\text { Rapid } \\
\text { treatment }\end{array}$ & $\begin{array}{l}\text { Reassurance } \\
\text { about limited } \\
\text { nature of local } \\
\text { skin reactions }\end{array}$ & $\begin{array}{l}\text { Reassurance about } \\
\text { safety of outcomes }\end{array}$ & Information & $\begin{array}{l}\text { Reassurance } \\
\text { of treatment } \\
\text { efficacy }\end{array}$ & $\begin{array}{l}\text { Reassurance } \\
\text { of treatment } \\
\text { safety }\end{array}$ \\
\hline $\begin{array}{l}\text { Focus of } \\
\text { treatment }\end{array}$ & $\begin{array}{l}\text { Fast, } \\
\text { effective } \\
\text { treatment } \\
\text { with short } \\
\text { duration }\end{array}$ & $\begin{array}{l}\text { Limited cosmetic } \\
\text { impact during } \\
\text { treatment; } \\
\text { predictable } \\
\text { downtime }\end{array}$ & $\begin{array}{l}\text { Limited cosmetic } \\
\text { impact after treatment; } \\
\text { predictable long-term } \\
\text { outcome }\end{array}$ & based approach & $\begin{array}{l}\text { Fast, } \\
\text { effective } \\
\text { treatment } \\
\text { with rapid } \\
\text { signs of } \\
\text { efficacy }\end{array}$ & $\begin{array}{l}\text { Treatment } \\
\text { decision } \\
\text { driven by } \\
\text { safety }\end{array}$ \\
\hline $\begin{array}{l}\text { Additional } \\
\text { management } \\
\text { suggestions }\end{array}$ & $\begin{array}{l}\text { Early } \\
\text { follow-up } \\
\text { Need for } \\
\text { guidance } \\
\text { and } \\
\text { motivation } \\
\text { from } \\
\text { physician }\end{array}$ & $\begin{array}{l}\text { Use pictures to } \\
\text { educate about } \\
\text { course of } \\
\text { treatment and } \\
\text { reactions } \\
\text { follow-up for } \\
\text { reassurance on } \\
\text { normal treatment }\end{array}$ & $\begin{array}{l}\text { Provide additional } \\
\text { information about } \\
\text { selected treatment } \\
\text { safety and outcomes } \\
\text { Emphasize } \\
\text { photoprotection }\end{array}$ & $\begin{array}{l}\text { Provide } \\
\text { supplementary } \\
\text { information } \\
\text { about treatment } \\
\text { efficacy and } \\
\text { safety to } \\
\text { support } \\
\text { treatment } \\
\text { choices }\end{array}$ & $\begin{array}{l}\text { Close } \\
\text { follow-up } \\
\text { Provide } \\
\text { additional } \\
\text { education } \\
\text { on the } \\
\text { realistic risk } \\
\text { of AK } \\
\text { evolution }\end{array}$ & $\begin{array}{l}\text { Early follow- } \\
\text { up } \\
\text { consultation }\end{array}$ \\
\hline
\end{tabular}




\begin{tabular}{|c|c|c|c|c|c|}
\hline & & $\begin{array}{l}\text { reactions and } \\
\text { outcomes }\end{array}$ & & & \\
\hline Notes & $\begin{array}{l}\text { Low } \\
\text { engagement } \\
\text { with disease } \\
\text { anticipated } \\
\text { to lead to } \\
\text { low } \\
\text { treatment } \\
\text { adherence } \\
\text { and } \\
\text { preventative } \\
\text { measures }\end{array}$ & $\begin{array}{l}\text { Consider } \\
\text { prescribing } \\
\text { moisturizing and } \\
\text { healing creams } \\
\text { for cosmetic } \\
\text { management of } \\
\text { local skin } \\
\text { reactions }\end{array}$ & $\begin{array}{l}\text { Consider prescribing } \\
\text { moisturizing and } \\
\text { healing creams for } \\
\text { improvement of long- } \\
\text { term cosmetic } \\
\text { outcome, including } \\
\text { early proper } \\
\text { photoprotection to } \\
\text { prevent } \\
\text { hyperpigmentation } \\
\text { (not only for } \\
\text { preventative but also } \\
\text { for cosmetic reasons) }\end{array}$ & $\begin{array}{l}\text { May be } \\
\text { unconcerned } \\
\text { about local } \\
\text { skin } \\
\text { reactions, } \\
\text { 'no pain, no } \\
\text { gain' }\end{array}$ & $\begin{array}{l}\text { This patient } \\
\text { may } \\
\text { particularly } \\
\text { benefit from } \\
\text { easy, direct } \\
\text { access to a } \\
\text { nurse or } \\
\text { dermatologist } \\
\text { through a } \\
\text { telephone } \\
\text { hotline }\end{array}$ \\
\hline
\end{tabular}


Table 4: Communication strategies for commonly encountered AK patient profiles*

\begin{tabular}{|c|c|c|c|c|c|c|}
\hline Profile & $\begin{array}{l}\text { Unengaged } \\
\text { (low medical } \\
\text { engagement) }\end{array}$ & $\begin{array}{l}\text { Cosmetic } \\
\text { concerned } \\
\text { during treatment }\end{array}$ & $\begin{array}{l}\text { Cosmetic } \\
\text { concerned } \\
\text { post- } \\
\text { treatment }\end{array}$ & $\begin{array}{l}\text { Knowledgeable } \\
\text { (high medical } \\
\text { engagement) }\end{array}$ & $\begin{array}{l}\text { Diagnosis- } \\
\text { anxious }\end{array}$ & $\begin{array}{l}\text { Safety- } \\
\text { anxious }\end{array}$ \\
\hline $\begin{array}{l}\text { Suggested } \\
\text { communication } \\
\text { style }\end{array}$ & $\begin{array}{l}\text { Simple and direct } \\
\text { communication - } \\
\text { avoid complex } \\
\text { terminology or } \\
\text { explanations }\end{array}$ & $\begin{array}{l}\text { Provide } \\
\text { reassurance on } \\
\text { predictability of } \\
\text { local skin } \\
\text { reactions and } \\
\text { their resolution }\end{array}$ & $\begin{array}{l}\text { Provide } \\
\text { reassurance } \\
\text { about } \\
\text { outcomes of } \\
\text { treatment }\end{array}$ & $\begin{array}{l}\text { Medical and } \\
\text { scientific style }\end{array}$ & $\begin{array}{l}\text { Simple and } \\
\text { direct } \\
\text { communication; } \\
\text { reassuring }\end{array}$ & $\begin{array}{l}\text { Reassuring; } \\
\text { provide } \\
\text { confidence in } \\
\text { the safety of } \\
\text { therapy }\end{array}$ \\
\hline $\begin{array}{l}\text { Communication } \\
\text { strategy }\end{array}$ & $\begin{array}{l}\text { Focus on } \\
\text { motivating the } \\
\text { patient on the need } \\
\text { for treatment now } \\
\text { vs potential for } \\
\text { surgery later }\end{array}$ & $\begin{array}{l}\text { Focus on } \\
\text { dermatologist } \\
\text { experience with }\end{array}$ & $\begin{array}{l}\text { Reassure } \\
\text { that intense } \\
\text { local skin } \\
\text { reactions do } \\
\text { not } \\
\text { negatively } \\
\text { influence } \\
\text { long-term } \\
\text { outcomes }\end{array}$ & $\begin{array}{l}\text { Provide } \\
\text { patients with } \\
\text { data, including } \\
\text { key statistics to } \\
\text { support an } \\
\text { evidence-based } \\
\text { approach }\end{array}$ & $\begin{array}{l}\text { Provide } \\
\text { objective } \\
\text { evaluation on } \\
\text { the risk of AK } \\
\text { evolution }\end{array}$ & $\begin{array}{l}\text { Acknowledge } \\
\text { anxiety and } \\
\text { explore - } \\
\text { 'What are } \\
\text { you most } \\
\text { concerned } \\
\text { about?' }\end{array}$ \\
\hline
\end{tabular}




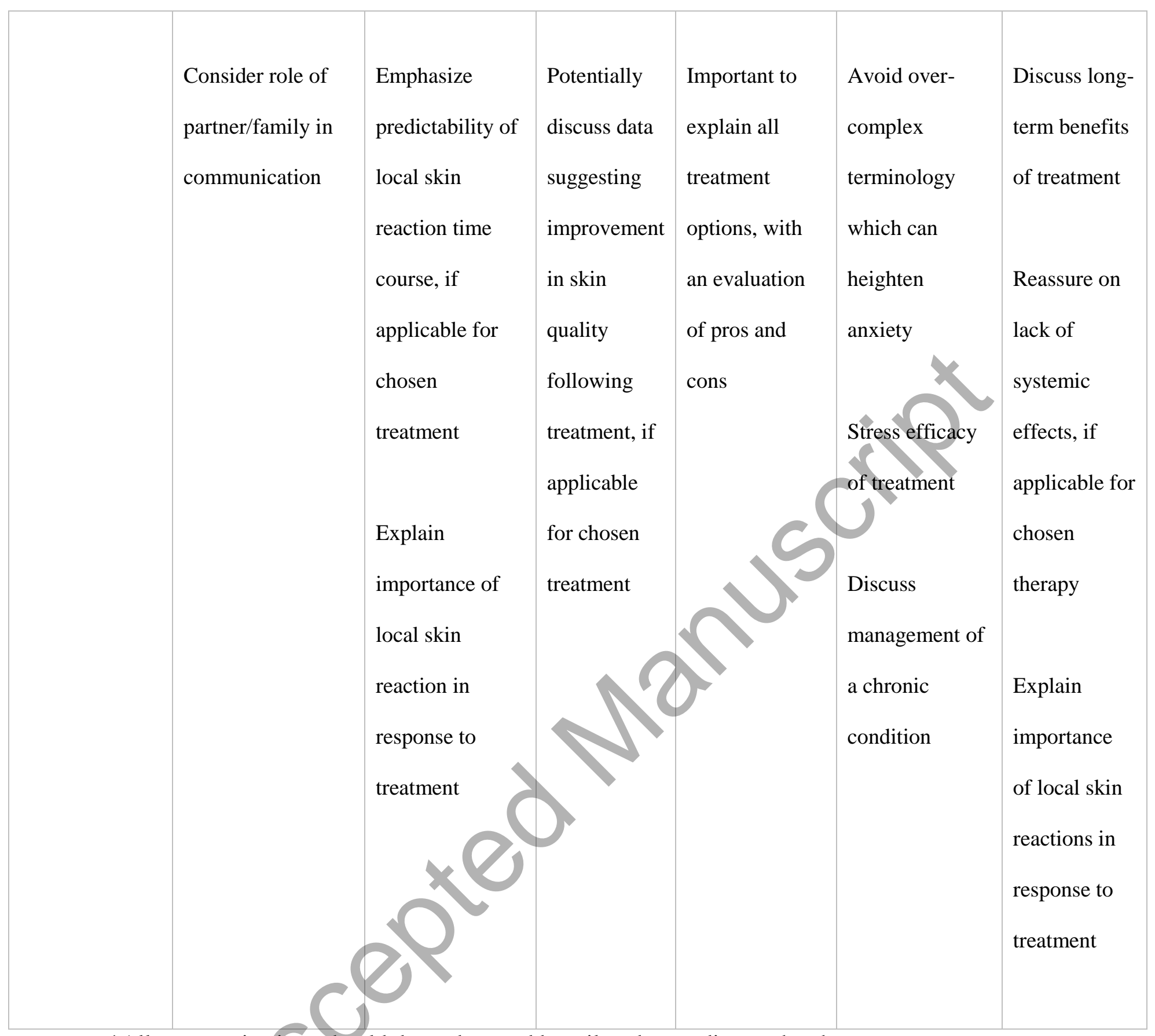

*All communications should depend on and be tailored according to the chosen treatment 
Table 5: Considerations for field-directed therapy* in commonly encountered AK patient profiles

\begin{tabular}{|c|c|c|c|c|c|}
\hline Profile type & Description & $\begin{array}{l}\text { Recommended } \\
\text { treatments } \\
\text { (in alphabetical order) }\end{array}$ & Rationale & $\begin{array}{l}\text { Treatments } \\
\text { not } \\
\text { recommended }\end{array}$ & Rationale \\
\hline $\begin{array}{l}\text { Cosmetic } \\
\text { concerned } \\
\text { during } \\
\text { treatment }\end{array}$ & $\begin{array}{l}\text { Concerned } \\
\text { with } \\
\text { cosmetic } \\
\text { effects } \\
\text { during }\end{array}$ & $\begin{array}{l}\text { Conventional/daylight } \\
\text { PDT } \\
\text { Ingenol mebutate }\end{array}$ & $\begin{array}{l}\text { Outcomes with noticeable but } \\
\text { short, predictable duration of } \\
\text { local skin reactions }\end{array}$ & Imiquimod & $\begin{array}{l}\text { Unpredictable } \\
\text { onset of local skin } \\
\text { reactions }\end{array}$ \\
\hline & & $\begin{array}{l}\text { Alternative: } \\
\text { Diclofenac }\end{array}$ & $\begin{array}{l}\text { Not recommended due to } \\
\text { unpredictable outcomes, but } \\
\text { an option for patients who } \\
\text { would potentially prefer } \\
\text { milder but longer lasting local } \\
\text { reactions }\end{array}$ & & \\
\hline $\begin{array}{l}\text { Cosmetic } \\
\text { concerned } \\
\text { post-treatment }\end{array}$ & $\begin{array}{l}\text { Concerned } \\
\text { with } \\
\text { cosmetic } \\
\text { outcomes of } \\
\text { treatment }\end{array}$ & $\begin{array}{l}\text { Conventional/daylight } \\
\text { PDT } \\
\text { Ingenol mebutate }\end{array}$ & $\begin{array}{l}\text { Potential for cosmetic } \\
\text { improvement of signs of } \\
\text { photo-aging following } \\
\text { treatment }\end{array}$ & 5-fluorouracil & $\begin{array}{l}\text { Use with caution, } \\
\text { overuse can lead to } \\
\text { severe blistering } \\
\text { resulting in } \\
\text { scarring }\end{array}$ \\
\hline
\end{tabular}




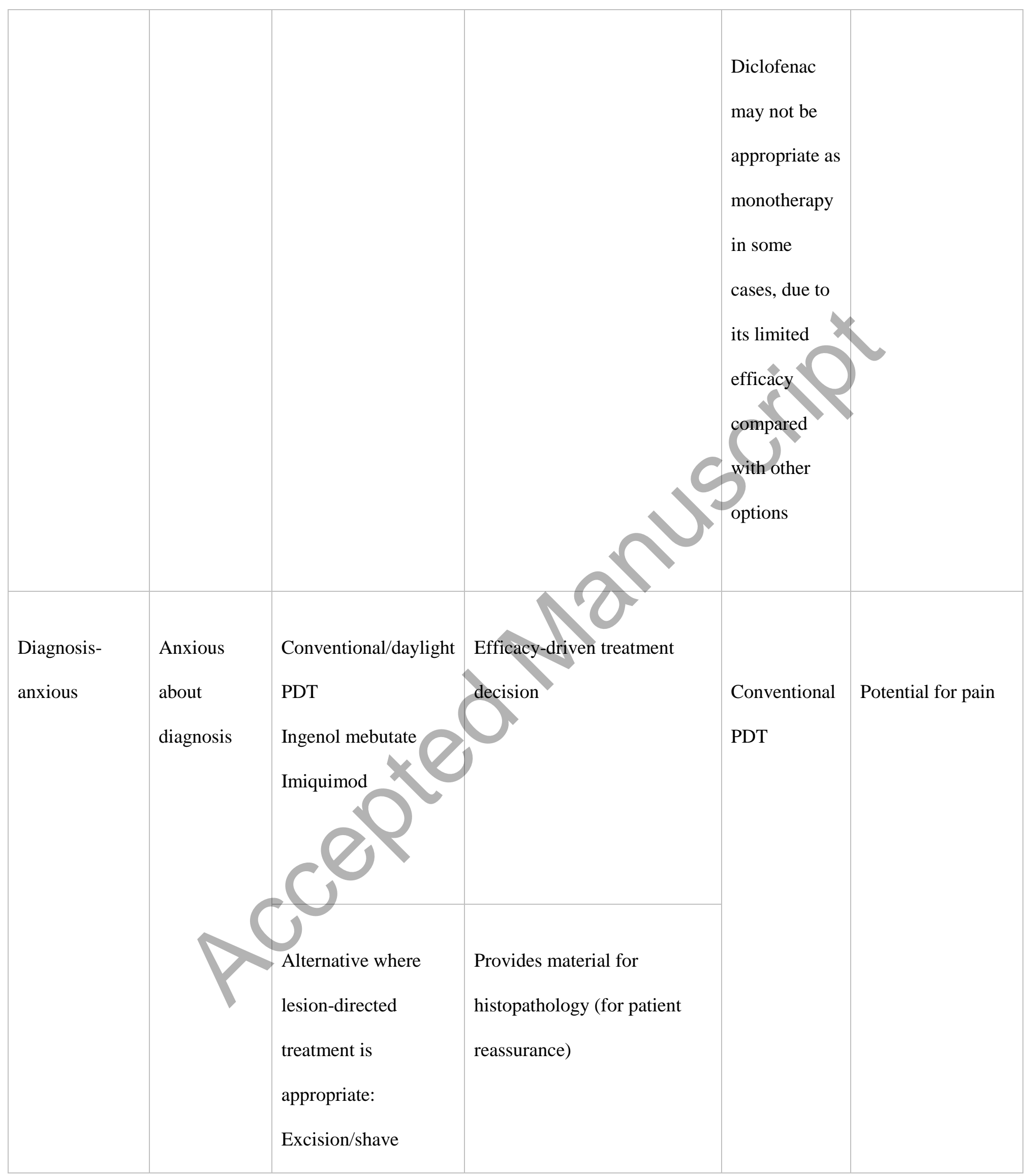




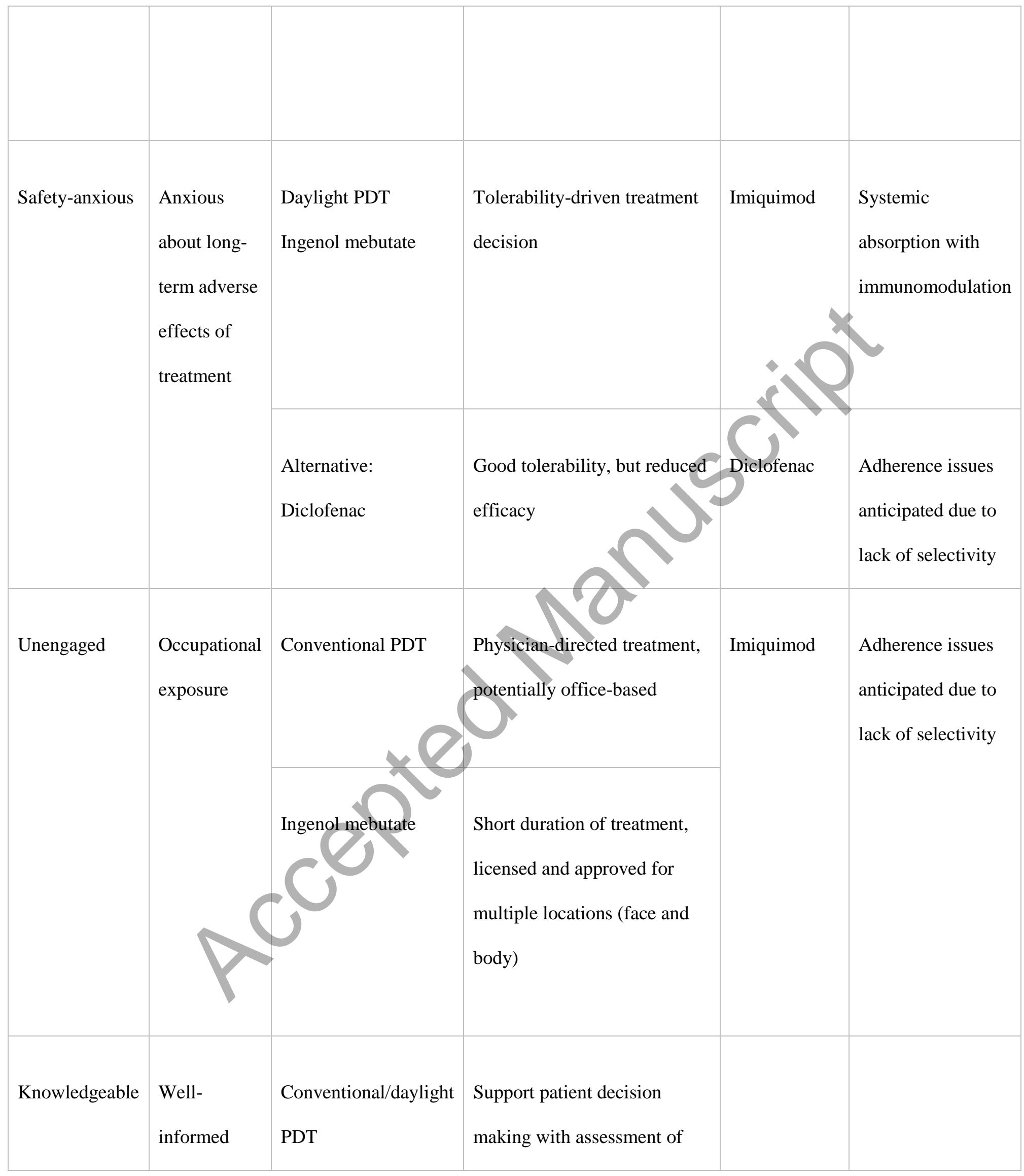




\begin{tabular}{|l|l|l|l|l|}
\hline patient & $\begin{array}{l}\text { Ingenol mebutate } \\
\text { Imiquimod }\end{array}$ & efficacy and safety of each & \\
treatment & & \\
\hline
\end{tabular}

*The panel does not recommend cryotherapy for these patient profiles as a lesion-directed treatment due to the potential for missing sub-clinical lesions, scarring, highly variable short and long term outcomes based on experience, and the requirement for multiple rounds of treatment. 